\title{
MICROWAVE NOISE TECHNIQUE FOR MEASUREMENT OF HOT-ELECTRON ENERGY RELAXATION TIME AND HOT-PHONON LIFETIME*
}

\author{
E. Šermukšnis, J. Liberis, and A. Matulionis \\ Semiconductor Physics Institute, A. Goštauto 11, LT-01108 Vilnius, Lithuania \\ E-mail: sermuksnis@pfi.lt
}

Received 2 July 2007; accepted 21 November 2007

\begin{abstract}
Gated modulation-type radiometric technique for microwave noise measurement is upgraded for convenient investigation of hot-electron energy relaxation and hot-phonon dynamics in a channel with a high-density electron gas. The technique is applied to a GaN-based structure held at 80 and $293 \mathrm{~K}$ channel temperature. The results are discussed in terms of hot-phonon effect on hot-electron energy relaxation. The hot-phonon lifetime, estimated from the noise analysis, is compared with the values obtained by more traditional techniques.
\end{abstract}

Keywords: GaN-based channels, hot electrons, hot phonons, microwave noise

PACS: $63.20 . \mathrm{Kr}, 72.20 . \mathrm{Ht}$

\section{Introduction}

Progress in semiconductor electronics is mainly associated with rapid shrinking of device dimensions. In order to achieve high currents needed for high power performance, the active region of a device usually contains a high electron density and operates at a strong electric field. This implies specific conditions for hotelectron energy relaxation. The accelerated electrons dissipate their excess energy on longitudinal optical (LO) phonons, and the latter tend to accumulate in the active region [1]. The accumulation causes additional scattering for the drifting electrons; the effect depends on the rate of disintegration of the nonequilibrium phonons into acoustic and other vibration modes [1]. The non-equilibrium LO phonons are called hot phonons [2]; the associated effects are often treated in terms of hot-phonon lifetime.

Subpicosecond pump-probe Raman scattering is the most direct technique for measurement of hot-phonon lifetime in a semiconductor [3]. The lifetime is determined from the decay of intensity of anti-Stokes line after the pump pulse. The problems arise when the channel dimensions shrink: thus, the technique has never been applied for the lifetime measurement in a

\footnotetext{
* The report presented at the 37th Lithuanian National Physics Conference, 11-13 June 2007, Vilnius, Lithuania.
}

single two-dimensional electron gas (2DEG) channel of importance for high-speed field-effect transistors [1]. Unlike this, the current fluctuations are generated exactly where the current flows. As a result, the noise technique for the lifetime measurement [4] is applicable to $2 \mathrm{DEG}$ and $3 \mathrm{DEG}$ channels. Supposing that the electron density per unit volume is the same, the noise technique yields the lifetime in GaN-based 2DEG channels $[1,4]$ comparable with the values obtained by the Raman technique for bulk GaN [3].

In this work, the main attention is paid to advancement of microwave noise technique for experimental investigation of electron scattering by hot phonons. The text is structured as follows. A block diagram of the gated-radiometric set-up is presented and principles of operation are explained. The main characteristics of the upgraded system are given together with explanations of stochastic signal measurements. Equations illustrate how one can extract the equivalent noise temperature of hot electrons from the measured noise power and the complementary data. A GaN-based channel is used as an example for illustration of the technique in action. The range of electric field and temperature is selected where the electron-LO-phonon scattering is the dominant energy dissipation mechanism. In this range, the noise temperature almost equals the hot-electron temperature, the power dissipation is 
activated by the hot-electron temperature, the activation energy equals to the LO-phonon energy. The nonequilibrium LO phonons are taken into account in order to interpret the experiment data in terms of hot-phonon lifetime.

\section{Microwave noise technique}

Noise temperature Tn of a resistor is obtained from the measured noise power. The noise power, dissipated by the resistor into a matched load, is called the available noise power $P_{\mathrm{n}}$ :

$$
P_{\mathrm{n}}=k_{\mathrm{B}} T_{\mathrm{n}} \Delta f,
$$

where $k_{\mathrm{B}}$ is the Boltzmann constant and $\Delta f$ is the bandwidth at which the noise power is measured. The available noise power differs from the measured noise power if the impedances of the sample and the load do not match. The mismatch is taken into account in different ways [5].

At equilibrium, the noise temperature is the same as the sample temperature. When the electrons are displaced from equilibrium by the applied electric field, the electron temperature exceeds that of the lattice [5]. As a rule, the longitudinal noise temperature of hot electrons exceeds the electron temperature since additional sources of noise act in the bias direction; noise due to electron temperature fluctuations, inter-subband noise, real-space transfer noise, shot noise are several examples [5-7]. On the other hand, the transverse noise temperature approximately equals the electron temperature. The transverse hot-electron noise can be measured on four terminal samples but these measurements are complicated [8].

Our measurements of the longitudinal noise temperature follow the procedure described in detail in Ref. [6]. The noise temperature of hot electrons is measured at $10 \mathrm{GHz}$ in the direction of bias, the bandwidth $(\Delta f=1 \mathrm{GHz})$ is mainly determined by the microwave amplifier. Figure 1 shows the schematic block circuit of the advanced gated radiometric set-up. A sample under test is mounted inside the waveguide and subjected to voltage pulses. The hot electron noise is generated during the voltage pulse. The pulse duration is short in order to avoid channel self-heating. The noise power emitted by the hot electrons is directed to the modulator through the waveguide commutator and the circulator, is amplified by the microwave low-noise amplifier, and detected by the microwave detector. The detector signal is also amplified and forwarded to the gated radiometer where the signal (proportional to the microwave noise power) is measured at appropriate time moments. The radiometer gate is opened twice during the voltage pulse repetition period $2 / f_{0}$ in order to compare the noise power due to the hot electrons with that of the standard noise source kept at a known temperature $\left(T_{0}=293 \mathrm{~K}\right)$. The both signals are subtracted later in the radiometer.

Only a part of the hot electron noise power is emitted because of reflection if the impedances of the sample and the waveguide do not match. The reflection coefficient $\rho$ depends on the differential resistance of the sample, while the resistance itself depends on the applied electric field and the temperature. The mismatch effect is taken into account as follows. Supposing that the sample is under bias and the calibrated noise generator is on, the noise power $x_{\text {ng }}$ detected by the radiometric set-up after the subtraction can be written as [6]

$$
x_{\mathrm{ng}}=\lambda\left[T_{\mathrm{n}}(1-\rho)+T_{\mathrm{g}} \rho-T_{0}\right],
$$

where $T_{\mathrm{g}}$ is the known noise temperature of the calibrated noise generator, $T_{\mathrm{n}}$ is the sample noise temperature, and $T_{0}$ is the room temperature; $\lambda$ is the transfer function which takes into account the amplification and the other linear operations processed in the radiometer.

In order to obtain $\rho$, the noise generator is switched off and the additional measurement is made for the biased sample:

$$
x_{\mathrm{n}}=\lambda\left[T_{\mathrm{n}}(1-\rho)+T_{0} \rho-T_{0}\right],
$$

where $T_{0} \rho$ is the contribution due to the attenuator.

Equations (2) and (3) can be used to find $\rho$ and $T_{\mathrm{n}}$. In order to obtain $\lambda$, the waveguide commutator replaces the sample with the terminator (short-circuit element). In this case, the detected power $x_{\mathrm{g}}$ is

$$
x_{\mathrm{g}}=\lambda\left[T_{\mathrm{g}}-T_{0}\right] .
$$

If some additional noise sources or attenuators exist in the waveguide line, they generate additional noise. Their contribution should be taken into account in Eqs. (2)-(4).

Stanford Research Systems NIM modules are used: gated integrator and boxcar averager module SR250, Quad fast amplifier SR240A, and computer interface module SR245. The gate width of SR250 can be adjusted from 2 ns to $15 \mu$ s for integration of the noise power while the gate is open. Cascaded wideband (DC$350 \mathrm{MHz}$ ) SR240A amplifiers amplify the signal after the microwave detector before the gating in order to achieve the optimal signal needed for the radiometer. 


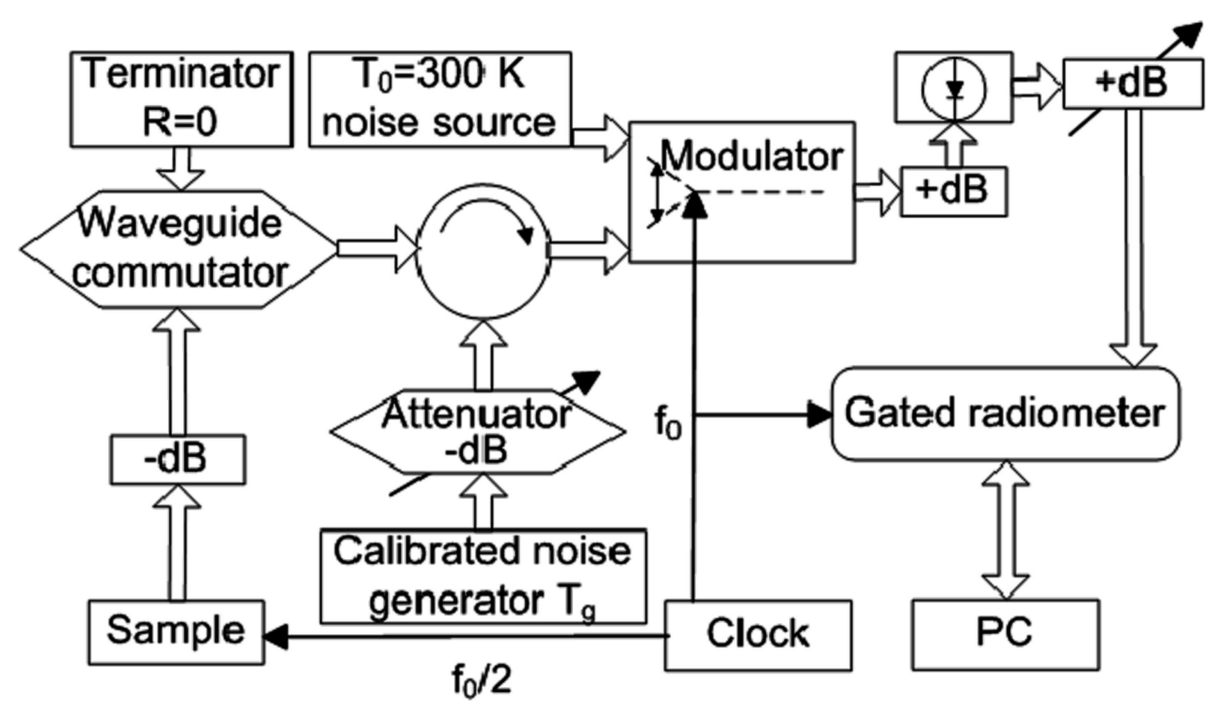

Fig. 1. Gated radiometric set-up for hot-electron noise measurements at $\mathrm{X}$ band microwave frequency (for details see text).

Each integrated noise value is averaged by the exponential moving averager contained in SR250. Every second value can be inverted before the averager. The inversion together with the averaging serves as subtraction. The computer module SR245 is connected with PC by RS232 interface. The averaged noise values are digitized in the computer module and loaded to the PC for further averaging. Our original Labview program is used to control the computer module and process the loaded noise values. The moving averaging in the radiometer and averaging in the $\mathrm{PC}$ are needed in order to increase the accuracy when the integration time is short. Standard deviation of the mean value is inversely proportional to square root of the averaging time, thus, after $N$ averages taken in PC, the total averaging time increases $N$ times. The voltage repetition frequency $\left(f_{0}<100 \mathrm{~Hz}\right)$ is relatively low in order to avoid sample self-heating. Because of long time needed to obtain a desired accuracy, the slow drift of the system is taken into account by calculating the power spectra of many averaged values.

\section{Sample}

The investigated sample is $\mathrm{GaN} / \mathrm{AlGaN} / \mathrm{GaN} /$ AlN/GaN heterostructure with a 2DEG channel designed, grown, and processed at University of California at Santa Barbara for a microwave high-power field-effect transistor [9]. The heterostructure is grown by metal-organic chemical vapour deposition onto sapphire substrate (Fig. 2). The 2DEG channel forms due to piezoelectric and polarization fields in the undoped GaN buffer layer near the AlN layer. The plane of donors (Si delta doping) supplies extra electrons for
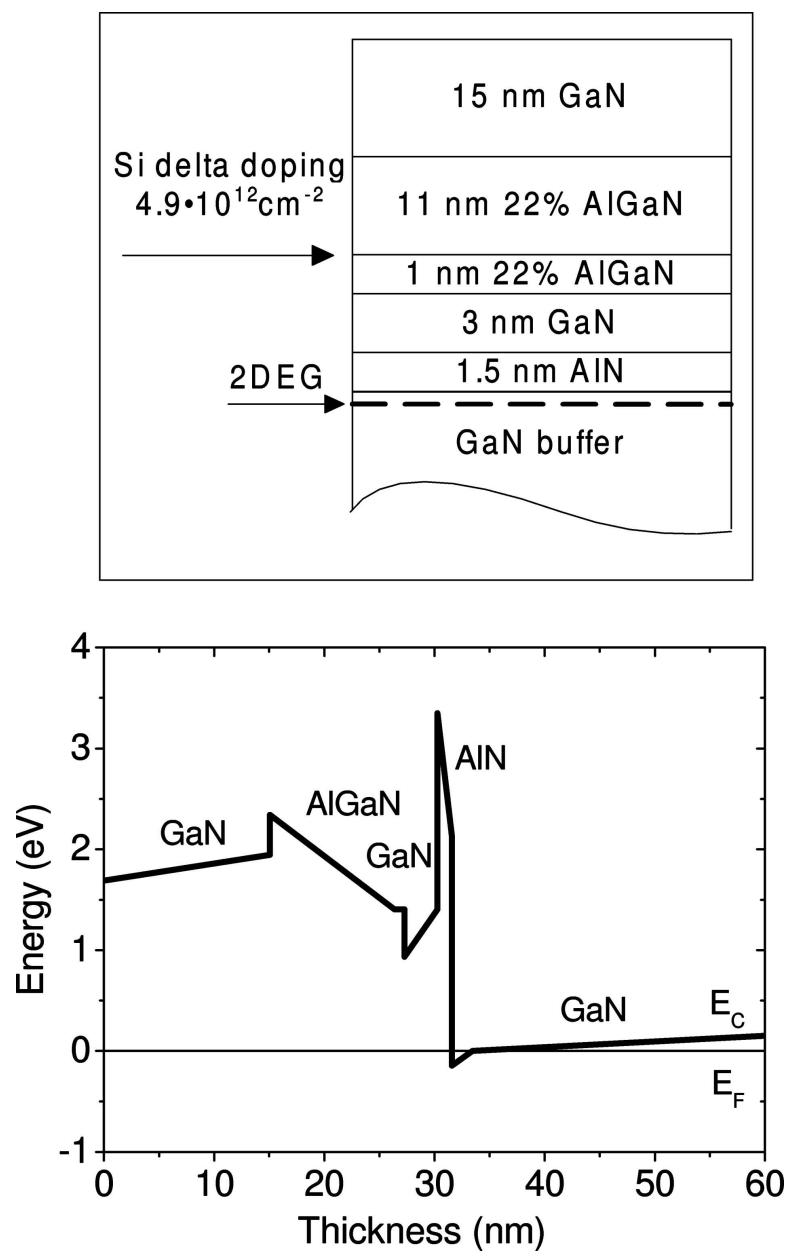

Fig. 2. Schematic illustration of composition and band diagram of $\mathrm{GaN} / \mathrm{AlGaN} / \mathrm{GaN} / \mathrm{AlN} / \mathrm{GaN}$ heterostructure.

the 2DEG channel. The thin AlN layer together with the GaN spacer helps to reduce the alloy scattering and the real-space transfer noise [10]. The electron 
sheet density $n_{2 \mathrm{DEG}}=4.92 \cdot 10^{12} \mathrm{~cm}^{-2}$ and the electron mobility $\mu=1468 \mathrm{~cm}^{2} /(\mathrm{V} \cdot \mathrm{s})$ are estimated from Hall effect measurements. For noise measurements, the channel is supplied with two coplanar ohmic electrodes. The channel length is $10 \mu \mathrm{m}$, the electrode area is $100 \times 100 \mu \mathrm{m}^{2}$. The estimated electron number in the channel is $N_{\mathrm{e}}=4.9 \cdot 10^{7}$. The electron volume density is around $n \sim 10^{19} \mathrm{~cm}^{-3}$ : the effective quantum well width is not known, and the value $d=4.8 \mathrm{~nm}$ is assumed (this value is available from calculations for a similar 2DEG channel [11]). The contact resistance is taken into account when the applied electric field and the noise temperature are estimated.

\section{Results}

Measurements are carried out in the range of electric fields and temperatures where intervalley and intersubband sources of noise play a negligible role. In this range, the longitudinal noise temperature can be expressed as [5]

$$
T_{\mathrm{n}}=T_{\mathrm{e}}+c T_{\mathrm{e}},
$$

where $T_{\mathrm{e}}$ is the hot-electron temperature; $c$ takes into account the hot-electron temperature fluctuations. When hot phonons are ignored, the factor $\mathrm{c}$ can be written through tensor components of conductance as

$$
c=\frac{T_{\mathrm{e}}}{4\left(T_{\mathrm{e}}-T_{0}\right)}\left(\frac{\sigma_{\|}}{\sigma_{\perp}}-1\right)^{2} \frac{\sigma_{\perp}}{\sigma_{\|}} .
$$

Here $\sigma_{\|}=\mathrm{d} I / \mathrm{d} U$ and $\sigma_{\perp}=I / U, I$ is the bias current, and $U$ is the voltage applied along the channel (voltage drop on contacts is subtracted). It is evident, that the factor $c$ is zero if Ohm's law holds. After Eqs. (5) and (6), the factor $c$ is small enough at electric fields below $10 \mathrm{kV} / \mathrm{cm}$ in our case. Hot phonons reduce the factor $c$ considerably $[12,13]$. Consequently, $T_{\mathrm{n}} \approx T_{\mathrm{e}}$ is an acceptable approximation in the investigated range of electric fields.

As mentioned, the voltage pulse should be short enough to avoid the channel self-heating effect on the noise temperature. The time-resolved noise measurements help to check whether the self-heating is important [14]. Noise temperature relaxation is measured after the voltage pulse. Since the electrons reach equilibrium with the lattice immediately (in several picoseconds), the noise temperature follows that of the lattice when the electric field is off. By measuring the lattice temperature at different time moments, an exponential decrease is obtained (the time constant of about

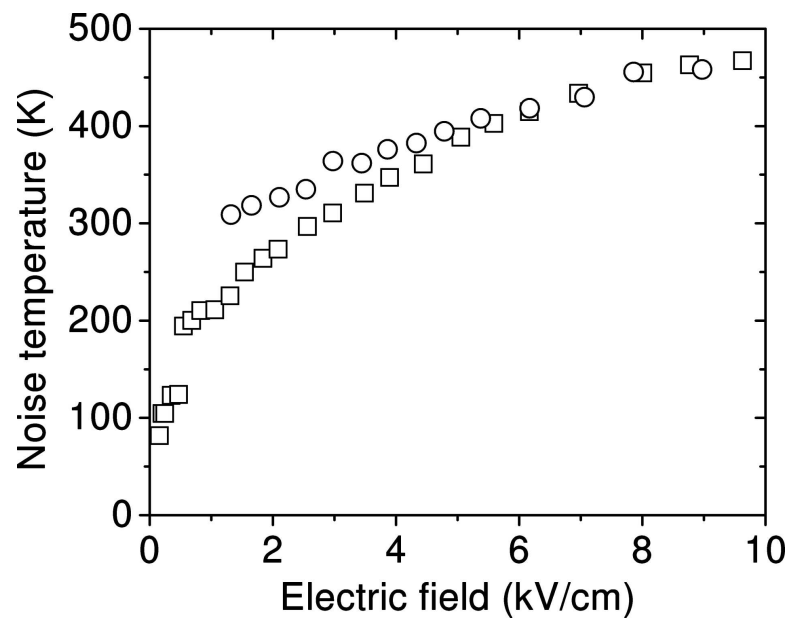

Fig. 3. Dependence of noise temperature on electric field at ambient temperatures $T_{0}=293 \mathrm{~K}$ (circles), $T_{0}=80 \mathrm{~K}$ (squares).

$400 \mathrm{~ns})$. Back-extrapolation of the exponential dependence gives the lattice temperature under bias.

The spectral density of current fluctuations can be obtained from the response and noise temperature data:

$$
\begin{aligned}
\frac{S_{I}(E)}{S_{I 0}}= & \frac{4 k_{\mathrm{B}} T_{\mathrm{n}}(E) \sigma(E) \Delta f}{4 k_{\mathrm{B}} T_{0} \sigma_{0} \Delta f}=\frac{T_{\mathrm{n}}(E) \sigma(E)}{T_{0} \sigma_{0}}= \\
& \frac{T_{\mathrm{n}}(E) \mu_{\mathrm{d}}(E)}{T_{0} \mu_{0}},
\end{aligned}
$$

where $E$ is the electric field, $\sigma$ and $\mu_{\mathrm{d}}$ are the hotelectron differential conductance and the differential mobility, $\sigma_{0}$ and $\mu_{0}$ are the conductance and the mobility at $E=0$. The spectral density of current fluctuations provides complementary data. For example, data of Fig. 3 show that the ambient temperature is not important for the noise temperature at high electric fields, but the same statement is not applicable to the spectral density of current fluctuations (Fig. 4).

In a resistor under steady-state non-equilibrium conditions, the power supplied to the electrons by the electric field $P_{\mathrm{S}}=U I$ is the same as the power dissipated by the hot electrons $P_{\mathrm{d}}$. The dissipated power can be expressed through the effective electron energy relaxation time $\tau_{\mathrm{e}}$ and the excess temperature $T_{\mathrm{e}}-T_{0}$ :

$$
\frac{P_{\mathrm{d}}}{N_{\mathrm{e}}}=\frac{U I}{N_{\mathrm{e}}}=\frac{k_{\mathrm{B}}\left(T_{\mathrm{e}}-T_{0}\right)}{\tau_{\mathrm{e}}},
$$

where $N_{\mathrm{e}}$ is the number of electrons in the channel. Since $U I / N_{\mathrm{e}}$ is known, the energy relaxation time $\tau_{\mathrm{e}}$ can be obtained from the noise temperature $T_{\mathrm{n}}$ data (Fig. 3) in the range of electric fields where Eq. (5) holds and $c \ll 1$. The data on energy relaxation (Fig. 5) illustrate the transition from the acoustic-phonon controlled energy dissipation to that dominated by LO 


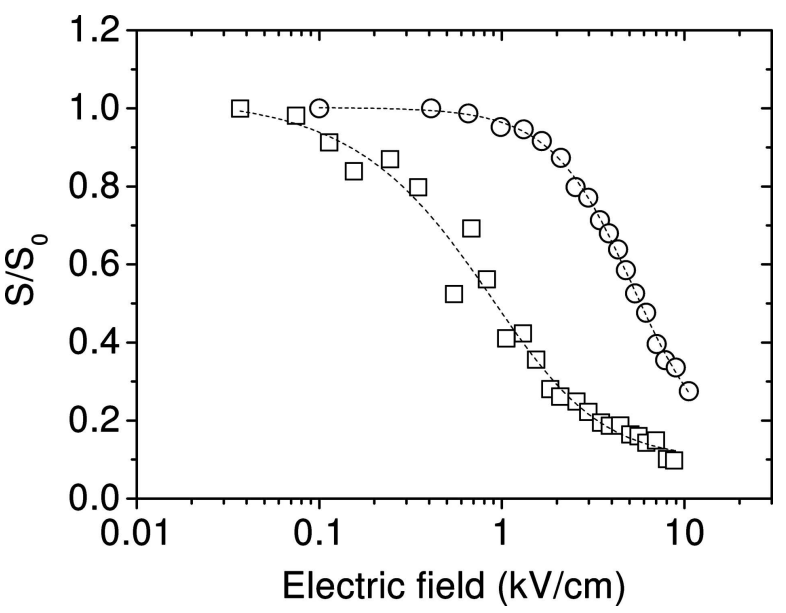

Fig. 4. Dependence of normalized spectral density of current fluctuations on electric field at ambient temperatures $T_{0}=293 \mathrm{~K}$ (circles), $T_{0}=80 \mathrm{~K}$ (squares).

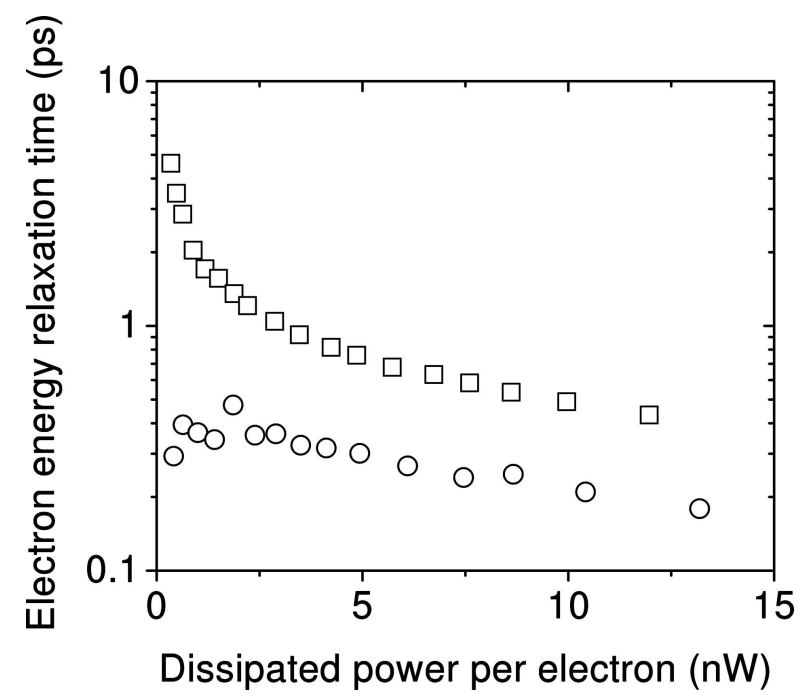

Fig. 5. Dependence of electron energy relaxation time on dissipated power per electron at ambient temperatures $T_{0}=293 \mathrm{~K}$ (circles), $T_{0}=80 \mathrm{~K}$ (squares).

phonons. At a low temperature, the dissipation through acoustic phonons is important. Optical phonons dominate at high electron temperatures.

When the ambient temperature is low and the dissipation through LO phonons dominates, the supplieddissipated power obeys Arrhenius-like dependence on the hot-electron noise temperature [4]:

$$
\frac{U I}{N_{\mathrm{e}}}=\frac{\Delta \varepsilon}{\tau_{\mathrm{ph}}} \exp \left(-\frac{\Delta \varepsilon}{k_{\mathrm{B}} T_{\mathrm{n}}}\right)
$$

where $\Delta \varepsilon$ is the activation energy and $\tau_{\mathrm{ph}}$ is the time constant.

The experimental data at $80 \mathrm{~K}$ (Fig. 6, squares) can be fitted with Eq. (9) if $\Delta \varepsilon=\hbar \omega$, where $\hbar \omega$ is the LO phonon energy ( $\hbar \omega=0.092 \mathrm{eV}$ ) (Fig. 6 , solid line).

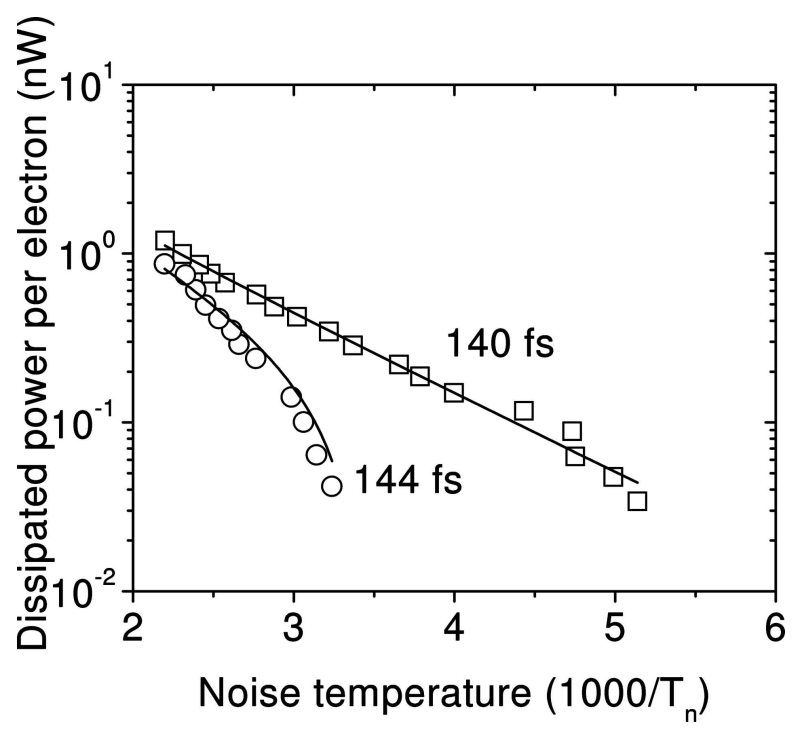

Fig. 6. Dependence of dissipated power per electron on inverse noise temperature at ambient temperatures $T_{0}=293 \mathrm{~K}$ (circles), $T_{0}=80 \mathrm{~K}$ (squares). Solid lines: Eq. (9) and Eq. (12) where $T_{\mathrm{n}} \approx T_{\mathrm{e}} \approx T_{\mathrm{ph}}$ is assumed.

The activation energy equals the LO-phonon energy in $\mathrm{GaN}$; this confirms that (i) the LO phonons are responsible for the dissipation and (ii) the noise temperature approximately equals the hot-electron temperature. The other fitting parameter is $\tau_{\mathrm{ph}}=140 \mathrm{fs}$. This time constant ( $\sim 140 \mathrm{fs})$ exceeds many times the spontaneous LO-phonon emission time, $\tau_{\mathrm{sp}}=10 \mathrm{fs}$ [15].

Equation (9) can be modified to include, in addition to the spontaneous emission of LO phonons, the stimulated emission of LO phonons, and the LO phonon reabsorption [4]:

$$
\frac{U I}{N_{\mathrm{e}}}=\left(1+f_{\mathrm{ph}}\right) \frac{\hbar \omega}{\tau_{\mathrm{sp}}} \exp \left(-\frac{\hbar \omega}{k_{\mathrm{B}} T_{\mathrm{e}}}\right)-f_{\mathrm{ph}} \frac{\hbar \omega}{\tau_{\mathrm{sp}}},
$$

where $f_{\mathrm{ph}}\left(T_{\mathrm{e}}\right)$ is the non-equilibrium occupancy of the hot-phonon states. The term "hot phonons" stands for non-equilibrium LO phonons [2]. The estimated LO phonon occupancy exceeds many times the equilibrium one when the hot-electron temperature is high enough. Expression (10) and the experimental data of Fig. 6 can be used to find the non-equilibrium occupancy $f_{\mathrm{ph}}$ and estimate the equivalent hot-phonon temperature $T_{\mathrm{ph}}[4]$ :

$$
f_{\mathrm{ph}}=\left[\exp \left(\frac{\hbar \omega}{k_{\mathrm{B}} T_{\mathrm{ph}}}\right)-1\right]^{-1} .
$$

The estimated hot-phonon temperature is below the electron temperature by several percent $[1,4]$. The hot phonons accumulate because their lifetime is much longer than the time constant for spontaneous emission. As a result, the hot electrons and the hot phonons form 
an almost isolated quasi-equilibrium hot subsystem and have approximately the same temperature [4]. The subsystem dissipates power when the LO phonons disintegrate. Thus, the dissipated power can be expressed in terms of the hot-phonon lifetime $[4,7]$ :

$$
\begin{aligned}
& \frac{U I}{N_{\mathrm{e}}}=\frac{\hbar \omega}{\tau_{\mathrm{ph}}}\left[f_{\mathrm{ph}}-f_{\mathrm{eq}}\right]=\frac{\hbar \omega}{\tau_{\mathrm{ph}}} \times \\
& \left(\frac{1}{\exp \left(\frac{\hbar \omega}{k_{\mathrm{B}} T_{\mathrm{ph}}}\right)-1}-\frac{1}{\exp \left(\frac{\hbar \omega}{k_{\mathrm{B}} T_{0}}\right)-1}\right),
\end{aligned}
$$

where $f_{\text {eq }}$ is the equilibrium LO-phonon occupancy at the ambient temperature.

Under a realistic assumption of $T_{\mathrm{e}} \approx T_{\mathrm{n}} \approx T_{\mathrm{ph}}$ $[4,7]$, equation (12) fits the experimental results of Fig. 6 (circles and solid line), and the fitting yields $\tau_{\mathrm{ph}}$. The fitting values for the hot-phonon lifetime range from 140 to 150 fs. These values are shorter than those reported for $\mathrm{AlGaN} / \mathrm{GaN}$ and $\mathrm{AlGaN} / \mathrm{AlN} /$ $\mathrm{GaN}$ channels $[1,4]$.

\section{Discussion}

The investigated microwave noise and the hotelectron energy relaxation illustrate the transition from the power dissipation controlled by acoustic phonons to that dominated by LO phonons. The transition temperature is in a reasonably good agreement with the earlier experimental data: the $\mathrm{LO}$ phonons dominate at $T_{\mathrm{e}}>$ $70 \mathrm{~K}$ when $T_{0}=1.5 \mathrm{~K}[15]$, at $T_{\mathrm{e}}>160 \mathrm{~K}$ when $T_{0}=$ $80 \mathrm{~K}$ [16], and at $T_{\mathrm{e}}>300 \mathrm{~K}$ when $T_{0}=293 \mathrm{~K} \mathrm{[6].}$ The Arrhenius-like dependence of the dissipated power on the inverse noise temperature (9) is valid at $80 \mathrm{~K}$, while the modified expression (12) holds at room temperature. The activation energy equals the LO-phonon energy in GaN. The experimental data support the following statements:

- the LO phonons are responsible for the power dissipation,

- the noise temperature approximately equals the hotelectron temperature, and

- the hot-electron temperature approximately equals the hot-phonon temperature.

These statements allow one to estimate the hot-phonon lifetime. The estimated lifetime ( $\sim 140 \mathrm{fs})$ is comparable with the hot-electron energy relaxation time measured at the highest electric field. At a high electric

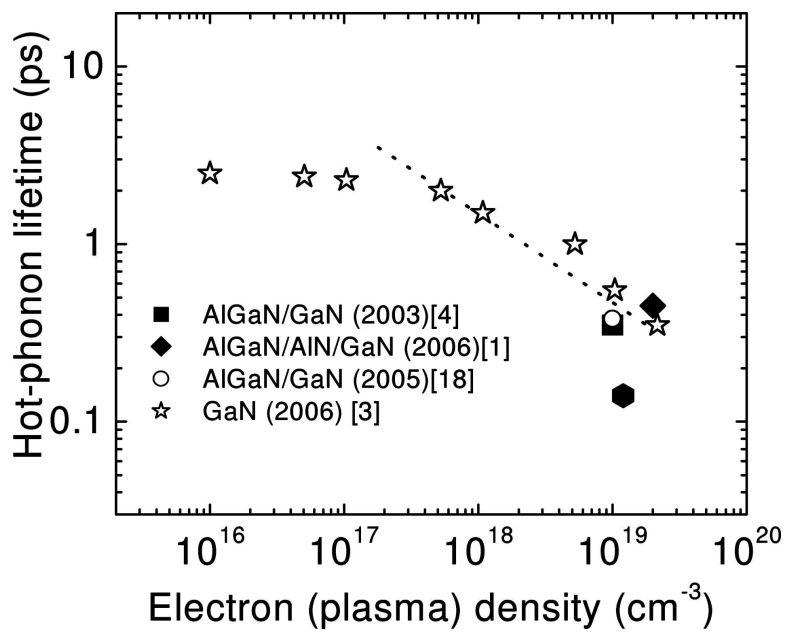

Fig. 7. Dependence of hot-phonon lifetime on electron density for GaN bulk and 2DEG channels. Open symbols correspond to timeresolved laser experiments: Raman scattering for bulk GaN (stars) [3] and intersubband absorbtion for $\mathrm{AlGaN} / \mathrm{GaN}$ (circle) [18]. Closed symbols are for microwave noise measurements of 2DEG channels: $\mathrm{AlGaN} / \mathrm{GaN}$ (square) [4], $\mathrm{AlGaN} / \mathrm{AlN} / \mathrm{GaN}$ (diamond) [1], and $\mathrm{GaN} / \mathrm{AlGaN} / \mathrm{GaN} / \mathrm{AlN} / \mathrm{GaN}$ (hexagon, present paper).

field, the measured energy relaxation time (Fig. 5) exceeds the value obtained through Monte Carlo simulation when hot phonons are not taken into account [17]. The hot-phonon effect on the electron energy dissipation manifests in the range of electric fields and temperatures where the electron scattering on LO phonons dominates.

The investigated 2DEG channel shows the lifetime values essentially below those reported for bulk GaN at a low density of electrons [3]. This difference is expected to result from the dependence of the lifetime on the electron density. Figure 7 compares the lifetime obtained for $\mathrm{GaN} / \mathrm{AlGaN} / \mathrm{GaN} / \mathrm{AlN} / \mathrm{GaN}$ (hexagon) with those reported earlier for GaN (stars) [3] and 2DEG channels (closed diamond, closed square, open circle) $[1,4,18]$. Different techniques lead to similar results if the electron density per unit volume is approximately the same.

\section{Conclusions}

Microwave noise measurements are suitable for investigation of fast and ultra-fast kinetic processes in semiconductors. The hot-electron microwave noise temperature method helps to obtain important kinetic parameters such as hot-electron energy relaxation time and hot-phonon lifetime. The lifetime in the invesigated $\mathrm{GaN} / \mathrm{AlGaN} / \mathrm{GaN} / \mathrm{AlN} / \mathrm{GaN}$ heterostructure with a 2DEG channel is shorter as compared with those 
measured for $\mathrm{AlGaN} / \mathrm{GaN}$ and $\mathrm{AlGaN} / \mathrm{AlN} / \mathrm{GaN}$ structures by the noise technique and for $\mathrm{AlGaN} / \mathrm{GaN}$ structure measured by the femtosecond-time-resolved optical-phonon-assisted infrared intersubband absorption technique.

\section{References}

[1] A. Matulionis, Hot phonons in GaN channels for HEMTs, Phys. Status Solidi A 203, 2313-2325 (2006).

[2] P. Kocevar, Hot-phonon dynamic, Physica B \& C 88, 155-163 (1985).

[3] K.T. Tsen, J.G. Kiang, D.K. Ferry, and H. Morkoc, Subpicosecond time-resolved Raman studies of LO phonons in GaN: Dependence on injected carrier density, Appl. Phys. Lett. 89, 112111 (2006).

[4] A. Matulionis, J. Liberis, I. Matulionienè, M. Ramonas, L.F. Eastman, J.R. Shealy, V. Tilak, and A. Vertiatchikh, Hot-phonon temperature and lifetime in a biased $\mathrm{Al}_{x} \mathrm{Ga}_{1-x} \mathrm{~N} / \mathrm{GaN}$ channel estimated from noise analysis, Phys. Rev. B 68, 035338 (2003).

[5] H.L. Hartnagel, R. Katilius, and A. Matulionis, Microwave Noise in Semiconductor Devices (Wiley, New York, 2001).

[6] A. Matulionis, J. Liberis, L. Ardaravičius, M. Ramonas, I. Matulioniene, and J. Smart, Hot-electron energy relaxation time in AlGaN/GaN, Semicond. Sci. Technol. 17, L9-L14 (2002).

[7] A. Matulionis and J. Liberis, Microwave noise in AlGaN/GaN channels, IEE Proc. Circuits Devices Syst. 151, 148-154 (2004).

[8] L. Ardaravičius, J. Liberis, A. Matulionis, and M. Ramonas, Estimation of electron energy relaxation time in 2DEG channels from transverse and longitudinal noise, Fluct. Noise Lett. 2, L53-L63 (2002).

[9] T. Palacios, L. Shen, S. Keller, A. Chakraborty, S. Heikman, S.P. DenBaars, U.K. Mishra, J. Liberis, O. Kiprijanovic, and A. Matulionis, Nitride-based high electron mobility transistors with a GaN spacer, Appl. Phys. Lett. 89, 073508 (2006).
[10] A. Matulionis, J. Liberis, O. Kiprijanovic, T. Palacios, A. Chakraborty, S. Keller, and U.K. Mishra, in: Proceedings of the 30th Workshop on Compound Semicondoctor Devices and Integrated Circuits in Europe (WOCSDICE 2006), ed. J. Stake (Chalmers University of Technology, Göteborg, 2006) pp. 165-166.

[11] M. Ramonas, A. Matulionis, J. Liberis, L. Eastman, X. Chen, and Y.-J. Sun, Hot-phonon effect on power dissipation in a biased $\mathrm{Al}_{x} \mathrm{Ga}_{1-x} \mathrm{~N} / \mathrm{AlN} / \mathrm{GaN}$ channel, Phys. Rev. B 71, 075324 (2005).

[12] X.L. Lei and N.J.M. Horing, Thermal-noise temperature of GaAs heterosystems for steady-state hotelectron transport with nonequilibrium phonons, Phys. Rev. B 36, 4238-4248 (1987).

[13] A. Matulionis, J. Liberis, and M. Ramonas, in: Noise and Fluctuations: 18th International Conference on Noise and Fluctuations - ICNF 2005, eds. T. González, J. Mateos, and D. Pardo, AIP Conf. Proc. CP780 (AIP, New York, 2005) pp. 105-108.

[14] L. Ardaravičius, J. Liberis, A. Matulionis, L.F. Eastman, J.R. Shealy, and A. Vertiatchikh, Self-heating and microwave noise in AlGaN/GaN, Phys. Status Solidi A 201, 203-206 (2004).

[15] N.M. Stanton, A.J. Kent, A.V. Akimov, P. Hawker, T.S. Cheng, and C.T. Foxon, Energy relaxation by hot electrons in $n$-GaN epilayers, J. Appl. Phys. 89, 973979 (2001).

[16] N. Balkan, M.C. Arikan, S. Golden, V. Tilak, B. Schaff, and R.J. Shealy, Energy and momentum relaxation of hot electrons in GaN/AlGaN, J. Phys. Cond. Matter 14, 3457-3468 (2002).

[17] T. Zubkute and A. Matulionis, Hot-electron energy dissipation and interelectron collisions in GaN-WZ, Semicond. Sci. Technol. 17, 1144-1148 (2002).

[18] Z. Wang, K. Reimann, M. Woerner, T. Elsaesser, D. Hofstetter, J. Hwang, W.J. Schaff, and L.F. Eastman, Optical phonon sidebands of electronic intersubband absorption in strongly polar semiconductor heterostructures, Phys. Rev. Lett. 94, 037403 (2005). 


\title{
MIKROBANGŲ TRIUKŠMŲ METODIKA KARŠTUৃJŲ ELEKTRONŲ ENERGIJOS RELAKSACIJOS TRUKMEI IR KARŠTU઼UU FONONŲ PUSAMŽIUI MATUOTI
}

\author{
E. Šermukšnis, J. Liberis, A. Matulionis \\ Puslaidininkiu fizikos institutas, Vilnius, Lietuva
}

\begin{abstract}
Santrauka
Mikrobangų triukšmų metodika panaudota labai spartiems kinetiniams vyksmams puslaidininkiniuose nanometriniuose dariniuose tirti. Esant kambario bei skysto azoto temperatūrai, elektrinių lauku stiprių srityje iki $10 \mathrm{kV} / \mathrm{cm}$ ištirtos nitridų protakos su dvimatemis elektronų dujomis. Pagal išmatuotą triukšmo temperatūrą îvertinta karštųjų elektronų temperatūra ir karštųju elektronų energijos relaksacijos trukmé: stiprèjant elektriniam laukui trukmė mažèja nuo 5 iki 0,2 ps. Silpnuose laukuose karštųjų elektronu energijos nuostolius lemia akustiniai fononai, bet stipriuose laukuose vyrauja nuostoliai per optinius fononus. Tik įskaičius nepusiausvirają karštuju fononų būsenų užpildą, savaiminę ir priverstinę optinių fononų emisiją bei jų sugerti pavyksta gauti neblogą eksperimentinių duo-
\end{abstract}

menų ir įverčių sutapimą. Nepusiausvirieji karštieji fononai dalyvauja intensyviuose energijos mainuose su karštaisiais elektronais, kai tuo tarpu energijos mainai su likusiais (pusiausviraisiais) fononais vyksta daug lèčiau. Todèl susidaro beveik atskirta nuo pusiausvirujų fononų karštoji elektronų ir optinių fononų posistemé, kurioje karštuju elektronų ir karštụju fononų temperatūros skiriasi nežymiai. Stacionariomis sąlygomis karštosios posistemès energijos nuostolius atsveria elektronų iš elektrinio lauko gaunama galia. Žinant galią ir įvertinus karštųjų fononų būsenų užpildą, ịvertinta karštujų fononu gyvavimo trukmè, lygi 140-150 fs. Ištirtoje elektrinių laukų srityje ji beveik nepriklauso nuo elektronų temperatūros. Triukšmų metodu ịvertintos trukmès palyginamos su vertemis, gautomis kitais metodais. 